\title{
A Risk-Based Framework for Safeguarding the European Commission's Independence
}

I have started this part of the book with the description of academic and political discourse surrounding the notion of judicial independence and outlined the principles formulated by the ECtHR on this subject. Chapter 9 described the objective environment in which EU competition law decisions are adopted and highlighted the political-bureaucratic interface that is engaged when the European Commission acts as an investigator, prosecutor and adjudicator during competition law enforcement proceedings. Chapters 10, 11 and 12 described the anatomy of the procedure leading to a competition law decision.

In the current chapter I will attempt to juxtapose the fair trial standards of independence developed by the ECtHR with the political-bureaucratic interface of the Commission. The purpose of this exercise is to test whether the European Commission can be deemed an independent and impartial adjudicator for the purpose of Article 6(1) ECHR.

\subsection{Identifying the Risks to Independence in EU Competition Law Proceedings}

I will follow a three-columned analysis in the current section, as Table 2 below indicates. This analysis will juxtapose procedural moments with the existing risks to the independent exercise of the adjudicative power and the existing safeguards.

The following procedural moments will be analysed:

- Steps taken by the EU Commission outside the framework of an official investigation;

- Official receipt of a formal complaint or a leniency application;

- Opening of an investigation or issuing of a statement of objections;

- Initial assessment and in-depth investigation of a complaint; and

- Formal adoption of a decision.

The following risks to independence will be interpreted:

- Interference-Describing potential involvement or influence over DG COMP by other directorates of the Commission or by one of the Commissioners; 
- External influence - Describing the potential involvement with or influence that lobbying groups or private interests may exercise over the Commission's employees;

- Anonymity - Describing the fact that the members of the DG COMP case team handling a competition law complaint are unknown to the public;

- Collegiality - Describing the collegiate nature of decision-making employed by the College of Commissioners;

- Appearances - Describing potential doubts that complainants or defendants may entertain about the Commission's independence;

- Cumulation of functions - Describing the concomitant exercise of investigative, prosecutorial and adjudicative functions by the EU Commission;

- Bias - Describing the preconceived ideas that staff involved in EU competition law proceedings might entertain due to their prior involvement with the case, the claimants or the defendants; and

- Momentum bias - Describing the risk that a lengthy investigation will lead to the adoption of a decision due to the time and resources spent investigating.

The last column of the analysis is dedicated to the existing safeguards that might counter the identified risks. These safeguards are the following:

- General behavioural safeguards - Describing EU law provisions concerning the independence of the EU Commission. General behavioural safeguards include the TFEU provisions concerning the independence of Commissioners, the Code of Conduct for Commissioners, the Staff Regulations, Rules of Procedure of the EU Commission and the Code of Good Administrative Behaviour. They were described in sections 9.1.2. and 9.2.2. above;

- Language requirements - Describing the obligation that the EU Commission has to communicate both with the complainants and the defendants in a language they can understand;

- Rights of defence - Describing the right to be heard that the defendants have and the involvement of the hearing officer with the proceedings;

- Meetings with the EU Commission - Describing state of play meetings, triangular meetings or bilateral meetings with the EU Commissioner for Competition or the Director-General of the DG COMP;

- Internal peer review - Describing the mechanisms put in place with the EU Commission for the purpose of ensuring checks and balances. These mechanisms describe the involvement of the Chief Economist, the EU Commission's Legal Service, the other DG s and the Advisory Committee; 
- Public scrutiny - Describing the accountability that derives from the public's knowledge about the competition law proceedings opened by the EU Commission; and

- Judicial review - Describing the judicial review performed by the CJEU.

TABLE 2 Risks to independent adjudication and existing safeguards in EU competition law

\section{Procedural Moment Risks to Independence Existing Safeguards}

\begin{tabular}{|c|c|c|}
\hline $\begin{array}{l}\text { Outside official } \\
\text { proceedings: } \\
\text { Agenda-setting } \\
\text { Monitoring by the } \\
\text { Commission } \\
\text { Informal complaints }\end{array}$ & $\begin{array}{l}\text { - External influence } \\
\text { - Interference } \\
\text { - Bias } \\
\text { - Appearances }\end{array}$ & $\begin{array}{l}\text { - General behavioural } \\
\text { safeguards }\end{array}$ \\
\hline $\begin{array}{l}\text { Receipt of formal } \\
\text { complaints } \\
\text { Receipt of leniency } \\
\text { application }\end{array}$ & $\begin{array}{l}\text { - External influence } \\
\text { - Interference }\end{array}$ & $\begin{array}{l}\text { - General behavioural } \\
\text { safeguards } \\
\text { - Language requirements }\end{array}$ \\
\hline $\begin{array}{l}\text { Opening of } \\
\text { investigation/ } \\
\text { Statement of } \\
\text { Objections }\end{array}$ & $\begin{array}{l}\text { - Interference } \\
\text { - Cumulation of functions } \\
\text { - Bias } \\
\text { - Anonymity }\end{array}$ & $\begin{array}{l}\text { - General behavioural } \\
\text { safeguards } \\
\text { - Public scrutiny } \\
\text { - Language requirements } \\
\text { - Rights of defence }\end{array}$ \\
\hline $\begin{array}{l}\text { Initial assessment and } \\
\text { in-depth investigation }\end{array}$ & $\begin{array}{l}\text { - External influence } \\
\text { - Interference } \\
\text { - Cumulation of functions } \\
\text { - Bias } \\
\text { - Anonymity } \\
\text { - Meetings with the EU } \\
\text { Commission }\end{array}$ & $\begin{array}{l}\text { - General behavioural } \\
\text { safeguards } \\
\text { - Language requirements } \\
\text { - Rights of defence } \\
\text { - Meetings with the EU } \\
\text { Commission }\end{array}$ \\
\hline $\begin{array}{l}\text { Formal adoption of } \\
\text { decision }\end{array}$ & $\begin{array}{l}\text { - Cumulation of functions } \\
\text { - Bias } \\
\text { - Momentum bias } \\
\text { - Collegiality } \\
\text { - Appearances }\end{array}$ & $\begin{array}{l}\text { - General behavioural } \\
\text { safeguards } \\
\text { - Internal peer review } \\
\text { - Public scrutiny } \\
\text { - Judicial review }\end{array}$ \\
\hline
\end{tabular}




\subsubsection{Risks to Independence Outside Official Proceedings}

It is important to notice that the EU Commission shapes EU competition policy and investigates breaches of competition law outside official proceedings as well. The political priorities set by the President of the Commission guide DG COMP's work during the whole mandate. At the same time, the DG COMP should monitor and gather information about the priority policy areas. Finally, as some authors have highlighted, DG COMP receives and settles informally competition law complaints. Allegedly, 9o\% of the competition cases that the Commission receives are settled informally. ${ }^{1}$

This situation raises serious concerns in relation to the independence of the EU Commission. First, since this off-procedure activity takes place outside the legal framework provided for by the existing hard law and soft law instruments in competition law, the risks of external influence, interference and bias are high. The only safeguards that apply to this type of competition law enforcement are the ones provided for by the Staff Regulations, the Rules of Procedure and by the Code of Good Administrative Behaviour, all of which are soft-law instruments. These general behavioural safeguards are sufficient for an administrative authority that has adjudicative powers. First, these standards do not clarify the involvement of the political branch of the Commission with the case. Since the enforcement of EU competition law requires the involvement of both the College of Commissioners and the DG COMP, the question arises as to how the College of Commissioners participates in the cases that are settled informally.

Second, questions about the practical aspects of handling informal complaints, such as the staff in charge of receiving the complaints or the procedure for negotiating an informal settlement, also raise serious questions about the independence of the EU Commission.

Lastly, it might be argued that this type of competition law-making yields large efficiency benefits in terms of competition policy making. However, this procedure rests on anonymity and gives the appearance that the EU Commission acts more like a secret service than a competition enforcement agency.

\subsubsection{Risks to Independence upon Receipt of Formal Complaints}

The receipt of a formal complaint or of a leniency application marks the beginning of formal competition law enforcement proceedings. This procedural moment activates the known legal framework for the enforcement

1 Van Bael, op. cit., p. 290. 
of competition policy in the EU and the rights of the defendants. A formal complaint or a leniency application also triggers the complainants' legitimate expectations that the Commission will reach a decision within a reasonable time and will correct the relevant market failure. In other words, this step marks the beginning of competition law proceedings whose course can be predicted by the parties involved and in which the Commission's powers will be exercised in a foreseeable way.

The risks to independence at this stage of the procedure are minimal. However, it is possible that external or internal pressure could be exercised on the staff receiving the complaints or involved with their preliminary handling. This pressure could be directed towards assigning lesser priority to cases or, on the contrary, assigning higher priority to cases.

\subsubsection{Risks to Independence during Opening of Proceedings}

The opening of proceedings, which in the case of cartel cases, coincides with the issuing of the statement of objections, marks the moment when defendants formally learn about the Commission's investigation and the evidence gathered against them. If the Commission issues a press release, the general public is also informed about the opening of the proceedings.

The risks to independence at this stage are important. First, there is the risk that staff involved in the off-procedure investigation of the case would be assigned to work as a case team. This means that staff members who might have spent years gathering information about the anti-competitive practices of the defendants would then be requested to act as prosecutors. Taking into account the organigram of DG COMP and its sectoral teams mentioned in Section 9.2.3. above, the probability that the same members of staff involved in investigation would be involved in the prosecution is very high. The alternative scenario would mean, for example, that staff from the division dealing with mergers in the energy sector might be required to be a part of the team prosecuting cartels in the big data sector. This scenario, although it might contribute to the Commission's independence, is very unlikely. DG COMP was praised during the two Eurobarometer exercises described in section 9.2.3. above as an administration with highly specialized teams. The reasoning that the EU courts use to defer to the discretion of the EU Commission on the grounds that the EU Commission is better-placed to acquire specialized knowledge on competition law matters might apply to the Commission's internal mechanisms as well. In fact, there might be an internal, sectoral deference within DG COMP that could affect the independent handling of complaints.

Second, the anonymity of the case-handlers can affect the independence of proceedings. Whereas the complainants and the defendants would have 
the opportunity to meet the members of the case team assigned by DG COMP to handle a case, the rest of the public does not know the names of the staff members involved with the case. This means that the public or the competition community is deprived of the possibility to identify DG COMP staff members who might have personal or economic links - such as owning shares with the defendants or the complainants. In this context, one can argue that European consumers - on whose behalf competition proceedings are initiated - should have the right to know the identity of the persons using public funds to prosecute breaches of competition law and to impose fines in the name of the public interest. Also, the anonymity of the prosecutorial function in this scenario diminishes the level of personal responsibility and accountability of each member of staff. Lastly, in light of the concerns raised during the Eurobarometer polls concerning the frequent changes of DG COMP's case team during proceedings, it seems fair to inquire into the reasons for these staff movements. Changes in the composition of case teams can strengthen independence by removing members who appear to be biased or linked to the complainants or the defendants. However, such changes might also weaken independent decision-making by removing case handlers who refuse to follow political instructions.

The existing safeguards at this stage are more meaningful than during other stages of competition law enforcement proceedings. The general behavioural safeguards are accompanied by safeguards stemming from publicity-driven accountability. Once the general public is informed about the proceedings, it can contribute to them by sharing information in support or against the EU Commission's proposed line of argument. In addition, the existing legal framework indicates that the statement of objections is issued in order to ensure the rights of defence of the defendants. However, rights of the defence in this context only refer to the right to be heard.

\subsubsection{Risks to Independence during Initial Assessment and In-Depth Investigation}

The initial assessment and the in-depth investigation performed by DG COMP are the stages of EU competition law proceedings during which the defendants have most rights and obligations. Defendants have the right to request state of play meetings, triangular meetings and meetings with the EU Commissioner for Competition or with the Director General for Competition. However, the Commission has full discretion when it comes to granting such meetings. What is more, when these meetings take place, the exchanges taking place during them are not public and do not thus form part of the case file. Hence, as the table above proposes, these meetings can be both a risk to independent 
decision-making and a safeguard. Since not enough is known publicly about them, it is difficult to propose a definite argument in favour of their assessment.

Unlike the meetings described above, for which the Commission retains full discretion concerning their approval, the Commission must organise one meeting to allow the defendant to be heard. The hearing is organised by the hearing officer, who reports directly to the EU Commissioner for Competition. The purpose of the hearing is to allow the defendant company to present its case to the Commission. However, in light of the whole enforcement procedure, it appears that such hearings are mere formalities. First, in light of the other meetings that can take place between the EU Commission and the defendants and which are off-record, it is important to understand what the added value of a hearing is other than ticking a box. This is particularly important both from the point of view of the length of proceedings and of the fact that these meetings are organized using public funds. Second, the hearing officer is, as the name suggests, only in charge of hearing the defendants. He is not a member of the case team and definitely not a specialist in the substantive issues raised during proceedings. The input of the hearing officer is thus more formal than substantive.

\subsubsection{Risks to Independence during Formal Adoption of Decisions}

The final step of EU competition law proceedings is the formal adoption of a decision. Independence at this stage of the proceedings faces serious risks. The case team that has so far cumulated investigative and prosecutorial powers is now also called to exercise adjudicative powers. In addition to the bias originating from the cumulation of functions, this step of the proceedings can also be influenced by a momentum bias. In fact, prior to the official initiation of proceedings, staff members of DG COMP might have spent a few years investigating the concerned market, handling complaints and choosing the complaint that has the highest probability of success. The opening of proceedings and the official investigation involve both the Commission's human resources and reputation capital. Thus, before the formal adoption of a decision, a variety of services from the Commission would have been involved with reading and reviewing the decision prepared and drafted by the DG COMP. Thus, the expectation of adopting the proposed decision might create a bias favouring the adoption of the decision.

The procedure for the adoption of EU competition law decisions can be either written or oral. It is well known that these decisions are long and incorporate complex economic analysis. It is also known that in the case of a written procedure, the Commissioners receive a proposed decision one week before 
its adoption. It is not clear how much in advance the Commissioners receive the proposed decision in case of oral procedure. It is also not clear if members of the Commissioners' cabinets have access to the proposed decision or if they can influence the Commissioner's opinion on it. Finally, it is unclear if the formal adoption of a decision is another instance of internal deferral to DG COMP's judgement or if the Commissioners truly take the time to consider the proposed decision. In view of the fact that the CJEU spends a few years on each competition law appeal, it might be argued that the College of Commissioners adopts the decision without examining the details of the case.

In any case, the decisions proposed by DG COMP are adopted by the College of Commissioners, a collegial institution. Dissenting votes may be voiced during the adoption procedure but are not made public. Whereas collegiality has its place in policy-making and institution-building, it sits oddly with the requirement that adjudicators be independent. It amounts to saying, "our institution thinks that you are guilty," and this, in turn, is a rather Orwellian approach to justice.

\subsection{Mitigating the Identified Risks}

The analysis that I have provided in the section 13.1. above described the risks to independence that may arise during EU competition law enforcement proceedings. For the purpose of identifying mitigating measures, I have identified four main types of risks:

- Off-record procedural risks arising from competition law enforcement that takes place outside the regular legal framework or from a lack of procedural rules;

- Structural risks resulting from the design of EU competition policy enforcement;

- Anonymity risks arising from the anonymity of DG COMP case handlers; and

- Collegiality risks arising from the collegiate nature of decision-making employed by the EU Commission.

Table 3 below categorises the risks identified in the enforcement of EU competition law proceedings by focusing on the procedural moments that raise most concerns in relation to independent decision-making.

\subsubsection{Off-Record Procedural Risks to Independence}

The off-record procedural risks to independent decision-making refer to investigative measures employed by the EU Commission before the opening of 
TABLE 3 Types of risks to independence in EU competition law

\section{Procedural Moment Risks to Independence Type of Risk}

$\begin{array}{lll}\begin{array}{l}\text { Outside official } \\ \text { proceedings: }\end{array} & - \text { External influence } & - \text { Off-record } \\ \text { Agenda-setting } & - \text { Interference } & \text { procedural risks } \\ \begin{array}{l}\text { Monitoring by the } \\ \text { Commission }\end{array} & - \text { Bias } & \\ \text { Informal complaints } & & \\ \text { Initial assessment and } & - \text { External influence } & - \text { Off-record } \\ \text { in-depth investigation } & - \text { Interference } & \text { procedural risks } \\ & - \text { Cumulation of functions } & - \text { Structural risks } \\ & - \text { Bias } & - \text { Anonymity risks } \\ & - \text { Anonymity } & \\ & - \text { Meetings with the EU } & \\ & \text { Commission } & \\ \text { Formal adoption of } & - \text { Cumulating functions } & - \text { Structural risks } \\ \text { decision } & - \text { Bias } & - \text { Anonymity risks } \\ & - \text { Momentum bias } & - \text { Collegiality risks } \\ & - \text { Collegiality } & \\ & - \text { Appearances } & \end{array}$

competition law proceedings or during the proceedings. These risks create the appearance that the EU Commission acts like a secret service agency collecting information about markets and undertakings outside the scope of formal investigations.

These risks could be mitigated by clarifying the applicable rules of procedure. First, DG COMP could publish the total number of complaints received yearly and the number of complaints per sectors. This would allow the general public to judge if the EU Commission is responding to complaints raised by the market or to its own political agenda. Second, DG COMP could publish the yearly number of informal settlements and the remedies imposed in these cases. Third, the applicable procedural framework could clarify the investigative measures the DG COMP can perform before the opening of proceedings. Last, the minutes of the meetings between the EU Commission and the defendants could be made part of the case file. 


\subsubsection{Structural Risks to Independence}

The structural risks to independent decision-making arise from the design of the EU competition enforcement system itself. These are, therefore, inevitable risks in the sense that any system designed in the same way would produce the same results. These risks concern the interference of the political branch of the EU Commission with the enforcement of EU competition law. They also concern the concomitant exercise by the EU Commission of investigative, prosecutorial and adjudicative powers.

Structural risks to independent decision-making stem from the fact that EU competition law enforcement has historically not been concerned with independence. Neither Regulation 1/2003, nor the implementing regulation mention independent decision-making. However, the constitutional design of the EU has dramatically changed with the adoption of the Charter of Fundamental Rights and the TFEU-imposed duty to accede to the ECHR. The new constitutional design of the EU requires the safeguarding of independent decision-making.

Despite their importance, structural risks are hard to address because they require changes to EU Treaties. At the same time, it would be possible to diminish the impact of the structural risks by creating a culture of independence within the EU Commission. As it has been shown above, the EU Commission has an autonomous bureaucracy. Autonomy, however, only complicates the efforts to create independent decision-makers. Whereas autonomy expresses the relationship between the political and the bureaucratic branches of an institution, independence qualifies first and foremost the relationship towards adjudicators and the act of adjudication. Both autonomy and independence are acts of self-centring, but autonomy seeks to ensure bureaucratic freedom of action from political interests in the institution, whereas independence protects the persons and the decision-making processes from influence, even by members of the bureaucracy itself.

Aside from constitutional remedies to mitigate structural risks to independence, a few measures could be implemented using soft-law instruments. First, the EU Commission could adopt a standard of independent decisionmaking when dealing with EU competition law. Unlike now, independence could become a guiding principle of decision-making. Second, DG COMP could assign separate teams of staff to investigate, prosecute and adjudicate cases. It would also be important to physically separate the team performing adjudicative functions in separate buildings in order to decrease the influence or pressure exercised on it. 


\subsubsection{Risks to Independence Posed by Collegiality}

Collegiality can be a risk because it diminishes the personal accountability of the Commissioners for the adopted decision. Collegiality, a typical feature of judicial decision-making, is not provided for by the EU treaties. It was the Commission itself, while adopting its own Rules of Procedure, that declared the collegiate nature of its decision-making.

Whereas collegiality can appear as a safeguard for independent adjudication, the contrary is achieved within the EU Commission. The Commissioners are politicians who, in the same day, must take decisions on numerous matters on their agenda. The Rules of Procedure provide for the same two procedures written or oral - to be employed for the adoption of all the items on the agenda. The fact that adjudication is treated by the EU Commissioners in the same way as the adoption of political matters raises separate issues of fairness. However, what appears of concern in the context of this analysis is the fact that collegiality prevents the defendants and other interested parties from contesting the independence of decision-making. Only if the adopted decision provided for a breakdown of the Commissioners' individual votes could the defendants show that certain Commissioners are linked to the complainants, that they consistently defend national politics or that they have endorsed opposing legal reasoning in the past.

Thus, changing the collegiality rules employed for the enforcement of EU competition law would not only strengthen the independence of the decisionmaking process, it would render the College of Commissioners more accountable and more diligent.

\subsubsection{Anonymity Risks to Independence}

The last type of risk to independent decision-making is posed by the anonymity of the case handlers. The risks presented by anonymity are similar to those presented by collegiality. Except for the lack of accountability, anonymity also increases the risk of interference by providing for the possibility of arbitrary removal of case handlers who might entertain minority views. In addition, anonymity also increases the risk of disclosure of information to defendants, complainants or third parties in a way that may pose serious concern to independent decision-making. DG COMP is aware of this risk as it highlights in its Annual Activity Reports the number of cases of inadvertent disclosure of information and the measures taken to correct the situation. ${ }^{2}$

2 See for example European Commission. Directorate-General for Competition. 2017 Annual Activity Report, quoted above, p. 54 . 
This type of risk is easy to address; the names of the case handlers could be disclosed starting with the opening of the proceedings and changes in team formation could be explained at least to the parties.

I have undertaken a difficult task in Part 3 of the current book: to test whether the European Commission fulfils the independence requirement imposed by Article 6(1) ECHR when enforcing EU competition law. In the course of the analysis, Chapter 7 described the growing importance of the administrative state and the issues raised by the required independence of the newlycreated regulators and of national competition authorities. At the same time, the administrative state brought about administrative institutions/agencies mandated to perform adjudicative tasks. Since judicial independence is a constitutional requirement imposed on the courts, the question of how judicial independence is to be understood in the context of administrative agencies performing adjudicatory functions is far from settled. This question is, however, of prime importance for the European Commission in light of the Union's commitment to democracy and to accede to the ECHR. The wider perspective offered in Chapter 7 stressed that the notion of independence is of concern both for national and international institution-building.

Chapter 8 was dedicated to the analysis of the ECtHR's case-law on the independence and impartiality of tribunals. The ECtHR's case-law indicates that member states can delegate adjudicatory tasks to administrative tribunals or agencies. At the same time, the ECtHR requires states to ensure independence of adjudication irrespective of the nature of the dispute. In other words, according to the case-law of the ECtHR, judicial independence should not be affected by the constitutional setup chosen by the state to provide adjudication.

What is more, as Section 8.4. suggested, the case-law of the ECtHR highlights a relationship between the seriousness of the dispute and the availability of safeguards protecting the independence of adjudication or judicial review. This conceptual framework was applied to test the EU Commission's independence.

Chapter 9 focused on the objective environment in which EU competition decisions are adopted and showed that they are prepared by the Directorate General for Competition - that is, by the bureaucratic side of the EU Commission - and are adopted by the College of Commissioners - that is, the political side of the EU Commission. In addition, the DG COMP cumulates investigative, prosecutorial and adjudicative powers when it enforces EU competition law. This set up suggests that independent adjudication cannot 
be presumed in EU competition law despite the fact that the EU has adopted a series of soft law instruments requiring both the Commissioners and the Commission's civil service to act independently.

Chapters 10, 11 and 12 focused on the anatomy of EU competition law decisions and described the procedures used by the EU Commission to enforce Articles 101 and $102 \mathrm{TFEU}$, the Commission's powers of investigation and the existing limits on its powers. This in-depth account showed that the EU Commission benefits from a wide discretion of action at all points during the procedure. This discretion allows the DG COMP to act off-record, by informally settling cases, to select the cases it wishes to pursue, to accept or reject meetings with the defendants and to impose large fines.

Based on the principle derived from the ECtHR's case-law - that disputes with serious consequences should provide for safeguards to preserve independent adjudication - Chapter 13 mapped the potential risks to the independence of the EU Commission when acting as an enforcer of EU competition law. Four types of risks were thus identified: off-record procedural risks, structural risks, anonymity risks and collegiality risks. Most of these risks are the result of the design of competition law system and mitigating them would require a change in the EU Treaties. Other risks to independent decision-making arise from the way in which the EU Commission has framed its own decision-making powers. These risks to independent decision-making could be mitigated by changes in practice.

Before closing this chapter, a clarification should be offered about the relationship between the right to be heard and independent adjudication during EU competition law proceedings. The right to be heard, together with other guarantees such as proportionality, do strengthen the appearance of fairness of the whole process. At the same time, these guarantees provide the defendants with actionable rights that also shape the Commission's actions. However, the relationship between the right to be heard and the right to an independent and impartial tribunal is not a direct one. An administrative tribunal can be fully independent and still disrespect the defendants' right to be heard. Also, a tribunal that is not independent can hear a defendant in a way that is compatible with the right to a fair trial. The two, however, are distinct classes of rights; they are not interchangeable and they should be satisfied concomitantly.

The relationship between the right to an independent and impartial tribunal and the right to an effective judicial review can be a direct one if - as the ECtHR has indicated - a lack of independence can be corrected during judicial review. If, on contrary, the lack of independence is due to a structural issue, it cannot be cured during judicial review. 
It can thus be concluded that, due to the objective environment in which EU competition law decisions are adopted and to the anatomy of the decisions, serious risks to independence exists in EU competition law. The large fines imposed by the EU Commission in competition law cases and the reputational cost of Article 101 or 102 TFEU proceedings represent serious consequences that should be accompanied by deep due process guarantees and in-depth judicial review. I will discuss at length the issue of correcting lack of independence through judicial review in Part 4. 
Cristina Teleki - 9789004447493

Downloaded from Brill.com04/26/2023 07:26:15AM via free access 